\title{
Production Method of Implant Prototype of Knee-Joint Femoral Component
}

Josef Sedlak, Martin Slany, Zdenek Fiala, Ales Jaros

Department of Machining Technology, Institute of Manufacturing Technology, Faculty of Mechanical Engineering, Brno University of Technology, Technická 2896/2, Brno 616 69, Czech Republic. E-mail: sedlak@fme.vutbr.cz, slany.m@fme.vutbr.cz, yfiala18@stud.fme.vutbr.cz, yjaros18@stud.fme.vutbr.cz

The paper deals with a design and construction of an implant prototype of a knee-joint femoral component with a complex shape mathematic description especially of functional (articulating) surfaces. The core of a technical solution labours under the thought of casing of femur distal part with a shell of certain thickness whereas a special area is used as a referential area defining an inner and outer shape of the shell. The area is marked, cropped and smoothed. It is the created area of the lower end of the patient femur respecting the overall curvature of the knee joint.

Within designing of the implant prototype of the femoral component of the knee-joint modern methods of getting CT data, their processing by CAD software called CATIA and subsequent post processing are applied.

The prototype implant of the femoral component of the knee joint is designed from processed CT data of the patient affected knee-joint (the femur distal part, a tibia proximal part). The 3D model of the implant prototype of the femoral component is created on the basis of data editing in CATIA software. The final 3D model is then located to the composition (a bone, the implant prototype) and using anchoring ribs it is fixed on the femur distal part.

Keywords: Knee-Joint, Implant Prototype, Femoral Component, Bone, CATIA

\section{Acknowledgement}

The research was supported and co-financed from the project called "Excellent young scientists at VUT University in Brno" - register number CZ.1.07/2.3.00/30.0039.

\section{References}

[1] MAHONEY, O., McClung, C., PHIL, M., SCHMALZRIED, T. (1999). Improved Extensor Mechanism Function with the Scorpio Total Knee Replacement, Orthopaedic Research Society Annual meeting. Available at: http://www.stryker.com/orthopaedics/sites/scorpioknee/scorpiorefs.php.

[2] VALENTININ, J., R., LEYES, M. AND SCHWEITZER, D. (1998). Spontaneous Osteonecrosis of the Knee. Treatment and Evolution. Journal Knee Surgery, Sports Traumatology, Arthroscopy. Volume 6, Number 1/January, p. 112.

[3] SALAI, M., DUDKIEWICZ, I., BLANKSTEIN, A., ISRAELI, A., CHECHIK, A. AND AMIT, Y. (2000). Bone Allograft in Revision Total Knee Replacement. Cell and Tissue Banking. Volume 1, Number 4/December, p. 214.

[4] ROUSSEAU, M., A., LAZENNEC, J., Y., AND CATONNE, Y. (2005). Early Mechanical Failure in Total Knee Arthroplasty International Orthopaedics. International Orthopaedics 10.1007/s00264-006-0276-7, p. 117.

[5] NADKARNI, J., B., AND CARDEN, D., G. (2005). Acute Locking in Revision Total Knee Arthroplasty due to Disengagement of the Locking Screw. Knee Surgery, Sports Traumatology, Arthroscopy, Volume 13, Number 3/April.

[6] PÍŠKA, M., SEDLÁK, J., CHARVÁT, O., MADAJ, M. (2010). Kloubní implantát, zejména kolenního kloubu. Patent Owner: Brno University of Technology, Brno, CZ, 2010. s. 5. Vydavatel: Industrial Property Office, Czech Republic. Document number: 21503. Document type U1. Registered: $29^{\text {th }}$ November.

[7] SEDLÁK, J. (2013). Moderní technologie výroby implantátu kolenního kloubu se specifickými požadavky na tvarové a funkční plochy: Habilitační práce. Brno: Brno University of Technology, Faculty of Mechanical Engineering, Department of Machining Technology, p. 179, 9 appendices.

[8] KAPANDJI, I., A.The Physiology of the Joints: Annotated Diagrams of the Mechanics of the Human Joints. $2^{\text {nd }}$ ed. London: E., 1970-74, 3 v. ISBN: 04430065471.

[9] $\quad$ CATIA ${ }^{\circledR}$ Version 5.20. [online]. ${ }^{\odot}$ Dassault Systemes 1998-2009. All rights reserved. [Date of retrieval $18^{\text {th }}$ March 2009]. Available at: http://www.3ds.com/products/v5-latest-release. 
[10] SEDLÁK, J., CHLADIL, J., SLANÝ, M., KOUŘIL, K. (2014). Introduction to Processing of CT Clinical Metadata of Disabled Part of Patient Knee Joint. Manufacturing TECHNOLOGY, Vol. 14, No. 4, p. 611618. ISSN: 1213- 2489.

[11] CHARVÁT, O., SEDLÁK, J., MADAJ, M. (2009). New Technique during Production of Knee Point Replacements. Strojírenská technologie, Vol. 2, No. XIV, p. 34-39. ISSN: 1211-4162.

[12] SEDLÁK, J., CHARVÁT, O., MADAJ, M. (2011). Technology of processing CT data of the Knee Joint. Manufacturing TECHNOLOGY, Vol. X, No. 1, p. 64-70. ISSN: 1213- 2489.

[13] PROCHÁZKOVÁ, J. (2007). Modelování matematických ploch v CAD systémech: Disertační práce. Brno: Brno University of Technology, Faculty of Mechanical Engineering, Institute of Mathematics. p. 163. Vedoucí disertační práce doc. PaedDr. Dalibor Martišek, Ph.D.

[14] PROCHÁZKOVÁ, J., PROCHÁZKA, D. (2006). The Application of Nurbs Surfaces in Engineering Practice. Sborník konference „Moderní matematické metody v inženýrství“. Brno: Brno University of Technology, Faculty of Mechanical Engineering, Institute of Mathematics.

[15] SEDLÁK, J., PROCHÁZKOVÁ, J. (2007). Direct B-Spline Interpolation of CNC Tool Trace from Cloadpoints. Strojírenská technologie, Vol. 2, No. 12, p. 1-4. ISSN: 1211-4162.

[16] PROCHÁZKOVÁ, J., SEDLÁK, J., PROCHÁZKA, D. (2007). Direct B-Spline Interpolation of CNC Path from Cloud of Points. In Proceedings of Symposium on Computer Geometry SCG 2007. Bratislava: STU Bratislava, p. 104-109. ISBN: 978-80-227-2734-1.

[17] SEDLÁK, J., PROCHÁZKOVÁ, J. (2007). Direct B-Spline Interpolation of CNC Tool Trace from Cloadpoints. Manufacturing Technology, Vol. 1, No. 7, p. 66-71. ISSN: 1213-2489.

[18] KODYS, M. (2011). Návrh metodiky tvorby 3D modelu femorální části kolenní náhrady: Diplomová práce. Brno: Brno University of Technology, Faculty of Mechanical Engineering, Department of Machining technology. p. 55, 2 appendices. Vedoucí diplomové práce Ing. Martin Madaj. 